\title{
TPO Receptor Agonist ONO-7746
}

National Cancer Institute

\section{Source}

National Cancer Institute. TPO Receptor Agonist ONO-7746. NCI Thesaurus. Code C96800.

An orally available small molecule and platelet thrombopoietin (TPO) receptor (TPOR; MPL) agonist with potential megakaryopoiesis stimulating activity. Upon administration, TPOR agonist ONO-7746 binds to and stimulates TPOR, which may lead to the proliferation and differentiation of megakaryocytes. In turn, this may increase the production of blood platelets and may prevent chemotherapy induced thrombocytopenia (CIT). TPOR is a cytokine receptor and member of the hematopoietin receptor superfamily. 